\title{
Destierro y género: condiciones e influencias del exilio mexicano en las artistas españolas tras la Guerra Civil
}

\section{Banishment and gender: conditions and influences of Mexican exile in Spanish artists after the Civil War}

\author{
IRENE BARRENO GARCÍA \\ Universidad Complutense de Madrid \\ irenebarreno9@gmail.com
}

\begin{abstract}
Resumen: Este trabajo pretende contribuir a una línea de investigación poco explorada hasta ahora: aquella que tiene por objeto de estudio la vida y obra de las artistas exiliadas en México al finalizar la guerra civil española. La experiencia del destierro influirá en estas mujeres de muy diversas formas, que afectarán tanto a su construcción identitaria en el país de llegada como a su producción artística. Pese a que la labor de la Historia del Arte debería ser la de recuperar sus testimonios, esta disciplina ha tendido a olvidarse de ellas, incluso en mayor medida que de sus compañeros varones. Se analizarán aquí por ello algunas implicaciones que tuvo el exilio particularmente para el género femenino, y se pondrán sobre la mesa distintas influencias y consecuencias que la migración tuvo para estas artistas a nivel de técnica, de soportes, de temas y de iconografías representadas.
\end{abstract}

Palabras clave: Exilio, México, arte, género, mujeres.

\begin{abstract}
This article seeks to contribute to a poorly explored line of research: that one which has as its object of study the life and work of women artists exiled in Mexico at the end of the Spanish Civil War. The experience of exile will influence these women in many different ways, affecting both their identity's construction in the country of arrival and their artistic production. Although History of Art's work should be to recover their testimonies, this discipline has tended to forget them, even more than their male colleagues. For that reason, we will analyze in this article some of the exile implications on female gender and we will study the different influences and consequences of the migration that affected these artists at their technical level, in their pictorial base, their represented themes and their iconographies.
\end{abstract}

Keywords: Exile, Mexico, art, gender, women.

Recibido: 15 de septiembre de 2020; aceptado: 31 de julio de 2021; publicado: 30 de septiembre de 2021. Revista Historia Autónoma, 19 (2021), pp. 97-121 e-ISSN: 2254-8726; https://doi.org/10.15366/rha2021.19.005 
1. El rechazo del franquismo a los intelectuales y el exilio. Consideraciones sobre el ambiente cultural mexicano a la llegada de los españoles

El 12 de octubre de 1936, fecha declarada por los fascistas como el "Día de la Raza y de la Hispanidad", José Millán-Astray, militar franquista fundamental para la creación de la Legión, pronunciaba en el Paraninfo de la Universidad de Salamanca su famoso ;Mueran los intelectuales! ${ }^{1}$. Esta frase era la perfecta síntesis del clima de rechazo a la actividad intelectual y artística que teñiría el país en los años venideros. En la España franquista, ser intelectual (y casi aún en mayor medida, ser artista) quedaba directamente relacionado con el judaísmo, el comunismo, la masonería, la homosexualidad y el anticristianismo, los males que habían causado todas las desgracias que asolaban al país en aquel momento. Enrique Suñer Ordóñez, así, se preguntaba:

\begin{abstract}
¿Quiénes son los máximos responsables de tantos dolores y tantas desdichas? Para nosotros no cabe la duda: los principales responsables de esta inacabada serie de espeluznantes dramas son los que, desde hace años, se llaman a sí mismos, pedantescamente, "intelectuales".
\end{abstract}

La misma línea encontramos en las afirmaciones del marqués de Quintanar: "Aquí no hay dos bandos que puedan parlamentar: de un lado está el ejército y el pueblo español, del otro una colección de intelectuales traidores y de asesinos profesionales. Hay que exterminarlos sin piedad"3.

Atendiendo a las diversas declaraciones de este tipo no resulta sorprendente que gran parte de la población obligada a exiliarse fueran personas pertenecientes al ambiente cultural. Como afirma Ascensión Hernández de León-Portilla, "la tragedia de la guerra civil española tuvo como resultado una transformación de la vida cultural de nuestro país en todos los ámbitos: el árbol derribado por el fascismo franquista dio sus frutos en México"4.

El período de exilio más arduo tuvo lugar durante el primer semestre de 1939. Esos meses se exiliaron entre 450000 y 500000 españoles, siendo el $15 \%$ intelectuales, catedráticos o artistas; en total, 70000 personas $^{5}$. Los principales destinos para los exiliados y exiliadas fueron Francia y México, representando el 70 \% de las acogidas. En México en 1939 existían dos organismos de fundamental importancia: el Comité Técnico de Ayuda a los Republicanos

\footnotetext{
${ }^{1}$ Muniesa i Brito, Bernat, Dictadura y transición: la dictadura franquista, 1939-1975, Barcelona, Universitat de Barcelona, 2005, p. 57.

${ }^{2}$ Marzo, Jorge Luis y Patricia Mayayo, Arte en España (1939-2015): ideas, prácticas, políticas, Madrid, Cátedra, 2015 , p. 26.

${ }^{3}$ Ibidem, p. 27.

${ }^{4}$ Hernández de León-Portilla, Ascensión, "El exilio español en México: cuatro momentos", en Revista de la Universidad de México, 76 (2010), p. 31. «https://www.revistadelauniversidad.mx/articles/2f6ccf41-9e22-49719c8d-53dcaf755a8f/el-exilio-espanol-en-mexico-cuatro-momentos»».

${ }^{5}$ Cf. Marzo, Jorge Luis y Patricia Mayayo, Arte en España ... op. cit., p. 30.
} 
Españoles (CTARE) dependiente del Servicio de Evacuación de Refugiados Españoles (SERE) y la Junta de Auxilio a los Republicanos Españoles (JARE). Fueron varias las motivaciones del gobierno mexicano para prestar esta ayuda a los españoles durante la guerra: su ideología de izquierdas, la percepción positiva de la llegada al país de trabajadores de muy distintos ámbitos, una lengua común y un factor que causaría malentendidos e incluso enfrentamientos: una supuesta relación histórica cultural y natural ${ }^{6}$.

Ha de tenerse en cuenta que dentro del pensamiento de izquierdas del México de aquel momento existían ciertas tendencias que rechazaban "lo español" por imperialista. Esto es algo que se manifestaría fervientemente en los artistas: los muralistas reivindicaban con persistencia las raíces y tradiciones del pueblo mexicano. Las iconografías relacionadas con sus antepasados aztecas eran una constante, y dentro de ese contexto los españoles jugaban un rol fundamental como sanguinarios conquistadores que arrasaron con la cultura nativa para imponer sus cánones eurocentristas. Tanto era este rechazo en ocasiones que en el enfrentamiento que surgiría entre el tradicional muralismo revolucionario y la vanguardia mexicana, los individuos pertenecientes al primer grupo menospreciarían a los vanguardistas acusándoles por su "cosmopolitismo europeísta, como si sus obras no hubieran surgido de las mismas raíces mexicanas"’7.

Los pintores y pintoras españolas además estaban ligados mayoritariamente a la pintura de caballete, algo que en el México revolucionario se rechazaba por considerarse burgués. Frente a estos tradicionales lienzos que solo las clases sociales más altas podían permitirse comprar, el muralismo pugnaba por un arte público, que se canalizaría en forma de murales que todo el mundo pudiese observar y que instruyesen al pueblo mexicano acerca de sus ancestros. Se trata por tanto de un contexto de tensiones en el que las y los artistas españoles experimentarían un proceso de adaptación e integración complejo y que fluctuaría según sus circunstancias específicas. Como explica Sebastián Faber, "hay tantas historias diferentes como hay exiliados"

Una consideración también a destacar de las artistas del exilio que aquí se tratarán es que generalmente los y las especialistas van a dividir su estudio entre las artistas de la primera generación y las de la segunda generación ${ }^{9}$. Las primeras fueron tanto aquellas que llegaron a México teniendo una edad más avanzada, y por ello habiéndose formado en su país natal y con un estilo maduro, como quienes, también adultas, se hallaban en formación. Las de la segunda generación serían quienes tuvieron que exiliarse con sus familias siendo muy pequeñas, de

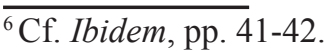

${ }^{7}$ Stanton, Anthony, "Poetas y pintores de la vanguardia mexicana: Xavier Villaurrutia y Agustín Lazo", en Millares, Selena (ed.), Diálogo de las artes en las vanguardias hispánicas, Madrid, Iberoamericana, 2017, p. 378. http:// dx.doi.org/10.31819/9783954875894-016

${ }^{8}$ Faber, Sebastián, "Silencios y tabúes del exilio español en México: historia oficial vs. historia oral", en Espacio, tiempo y forma. Serie V, Historia contemporánea, 17 (2005), p. 375. «http://revistas.uned.es/index.php/ETFV/ article/view/3112».

${ }^{9}$ Cf. Cabañas Bravo, Miguel, "Los artistas del exilio de 1939 en México. Caracterización y panorámica", en Laberintos: revista de estudios sobre los exilios culturales españoles, 17 (2015), pp. 100-101. «http://digital.csic. es/handle/10261/130730"r.
} 
manera que comienzan a desarrollar su carrera directamente en México pero con una confluencia de tradiciones española y mexicana. Esto, de nuevo, generará escenarios muy distintos en los que cada artista ha de ser estudiada según sus particularidades.

\section{Mujer y exilio}

Entre 1939 y 1945 llegaron a México un total de 19267 exiliados. Dentro de esta cifra, 8108 fueron mujeres; supusieron un $41,2 \%$ del cómputo tota ${ }^{10}$. A pesar de datos como este, no será hasta los años 80 del siglo pasado, y gracias a la perspectiva feminista que comenzaba a implementarse en las ciencias humanas, cuando se comience a estudiar el concepto del exilio teniendo en cuenta las cuestiones de género. En la mayoría de estudios sobre las migraciones históricamente se ha concebido a las mujeres como personas que tan solo emigraban para reunirse con sus maridos o padres ${ }^{11}$. Esto dejaba evidentemente de lado la dimensión económica y política de las migraciones o el exilio de las mujeres.

Por tanto, parece necesario continuar con una tradición de renovación historiográfica a la que, afortunadamente, cada vez contribuyen más autoras, como las que irán apareciendo a lo largo de este artículo y sin cuyas aportaciones este estudio no hubiera sido posible. Es de vital importancia pugnar por un estudio de las mujeres como protagonistas de su propio exilio, y no como complemento del de otros. Ha de analizarse el papel que juega el género en la configuración de las identidades que se produce en el exilio. En relación con esta cuestión de las identidades exiliadas, Alicia Alted afirma: "Todo abandono, voluntario o involuntario, pero forzado, del lugar de donde se es originario, lleva consigo el problema de la identidad [pues] se divide y fragmenta su mundo interior y su entorno circunstancial" ${ }^{12}$. Al ser el género una construcción social que determina las experiencias y las formas de relacionarse con el mundo de cada individuo, ha de entendérsele como una más de todas las condiciones psico-sociales que confluyen en la construcción identitaria producida cuando se modifican las condiciones materiales de los individuos.

Dentro de las implicaciones que tendrá el género en la cuestión del exilio, existe una muy llamativa que ha sido subrayada en distintas ocasiones: la condición de la mujer como doblemente exiliada, condición que no presentan sus compañeros varones. La mujer será

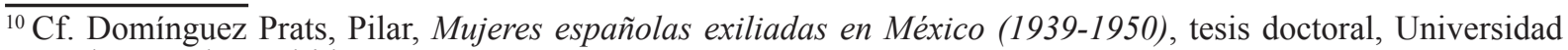
Complutense de Madrid, 1992, p. 130.

${ }^{11}$ Cf. Sanfilippo, Matteo, "Mujeres y emigración: la otra mitad de los flujos migratorios. La historiografía sobre las mujeres protagonistas y testigos de las migraciones", en Almela Boix, Margarita et al. (coords.), Mujeres en la frontera, Madrid, Universidad Nacional de Educación a Distancia, 2013, pp. 15-16.

${ }^{12}$ Alted, Alicia, "Las mujeres del exilio español: el paso de frontera como ruptura en las mujeres exiliadas", en Almela Boix, Margarita et al. (coords.), Mujeres en... op. cit., p. 39.
} 
exiliada como española republicana, es decir, por motivos políticos. Pero también será exiliada en un mundo hecho por y para hombres, como ciudadana, como ente inserto en una sociedad cuyos parámetros no contemplaban una existencia no masculina ${ }^{13}$. Este hecho ha sido señalado por ejemplo en el estudio Mujeres en la frontera: "Si las mujeres son por definición 'extranjeras' en el mundo patriarcal [...] ¿acumulan en la migración una doble extranjería?"'14. También en el testimonio de Neus Català, republicana exiliada que fue deportada por los nazis al campo de concentración de Ravensbrück. Ella, ante la invisibilización de las mujeres españolas reclusas en el campo y el hecho de que solo se tuvieran en cuenta los testimonios masculinos, afirma: "las mujeres fuimos las olvidadas entre los olvidados"15.

Además, particularmente en el caso de las artistas que aquí se estudian ha de atenderse a otra doble realidad. Estas mujeres realizarían un doble esfuerzo: en primer lugar, y como sus compañeros masculinos, por integrarse en una realidad artística extranjera. Por otra parte, un esfuerzo por intentar sobrellevar su actividad artística a la par que se encargaban de la totalidad de las labores del hogar. Un hogar que, en adición, pasaba grandes dificultades económicas para mantenerse en la mayor parte de los casos.

\section{Algunas influencias del exilio y el arte mexicano en la obra de las artistas españolas}

Desgraciadamente, no son muchos los estudios dedicados a analizar la vida y obra de las artistas españolas exiliadas en México tras la Guerra Civil. A nivel historiográfico, las investigaciones más recientes han sido realizadas por Carmen Gaitán Salinas. Esta autora ha recopilado en un ingente trabajo de archivo la información, que en muchas ocasiones aún no había sido sacada a la luz, acerca de las obras, exposiciones, y contratos de las artistas aquí analizadas. Sobre esta base se pretende ahora entrar en una contextualización y un análisis de su obra que permita continuar haciendo Historia del Arte con respecto de las mujeres artistas. Esta disciplina, tradicionalmente, cuando no se ha olvidado de ellas, se ha dedicado a presentar su vida y obra tan solo mediante datos, sin entrar en un análisis profundo, sin estudiar las implicaciones sociológicas que han derivado en la elección de una u otra iconografía, de una u otra técnica. Es a este tipo de investigaciones a las que se dedicará el presente apartado, tratándose de aproximar a las distintas influencias que el exilio tuvo en su arte.

\footnotetext{
${ }^{13}$ Sobre esta concepción de la mujer como alteridad, ver De Beauvoir, Simone, El segundo sexo, Madrid, Cátedra, 2014, pp. 47-56.

${ }^{14}$ Almela Boix, Margarita et al. (coords.), Mujeres en ... op. cit., p. 9.

${ }^{15}$ Català, Neus, entrevista realizada por Olga Merino, Barcelona, 13 de abril de 2013.
} 


\subsection{Relación entre exilio, arte y política}

Tanto la vida de las y los artistas exiliados como su propia producción artística ha sufrido generalmente un proceso de despolitización. Se puede afirmar, además, que este proceso ha sido doble y se ha desarrollado en distintos momentos históricos. Por un lado, encontramos cómo ya en el momento de su exilio, en su época contemporánea, a la gente llegada a México que venía de una actividad política muy participativa, se le negaba la posibilidad de participar en la política mexicana ${ }^{16}$, cercenándoseles una parte fundamental de lo que había sido su vida hasta aquel entonces. Por otra parte, ha existido lo que se podría entender como una despolitización a nivel historiográfico; como señala Javier Muñoz Soro, la memoria del exilio y su cultura ha sido despojada de muchos de sus elementos políticos y conflictivos para tratar de lograr una sensación de unidad en parte ficticia ${ }^{17}$.

Esto ocurre de forma mucho más descarada en el caso de las mujeres. Como se mencionaba anteriormente, un comportamiento habitual ha sido eliminar la carga política de su exilio para entenderlo exclusivamente como un "complemento" del destierro político de los hombres que les rodeaban. Pero esta despolitización también ha afectado a su obra, y a la manera en la que la historiografía, la investigación y la divulgación han construido el discurso sobre sus creaciones.

Para ilustrar esta problemática nos acercaremos a dos artistas de la primera generación, que emigraron adultas, y que contaban con un posicionamiento político claro. Partiendo de esta base, analizaremos cómo a raíz del exilio se transforman sus iconografías y representaciones de temas explícitamente políticos. Pretendemos visibilizar, en primer lugar, que en el hecho de que las mujeres no siempre pudieran producir obras manifiestamente políticas influían por ejemplo factores como los contratos (en los que intervenía de manera evidente la cuestión del género). Pero, no obstante, además de esas iconografías manifiestamente políticas, parece necesario, de cara a la incorporación de una metodología de investigación y análisis feminista de la Historia del Arte a la que nos adherimos, ahondar también en la amplia definición de lo político que puede contemplarse en relación con sus producciones artísticas en México.

El primer ejemplo lo constituye la artista Manuela Ballester. Esta se exilia en 1939, tras haber militado en las filas comunistas y colaborado con la República. El activismo político será una constante en su obra anterior al exilio. En los años 30 formó parte del denominado "realismo español" de la vanguardia valenciana. En sus obras de este período puede apreciarse una mezcla de arte y compromiso político. Participó en el Comité de Mujeres Antifascistas y dirigió su revista Pasionaria, en la que animó a las mujeres a tomar conciencia contra los modelos patriarcales de la sociedad capitalista ${ }^{18}$.

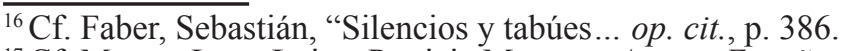

${ }^{17} \mathrm{Cf}$. Marzo, Jorge Luis y Patricia Mayayo, Arte en España... op. cit., p. 25.

${ }^{18}$ Cf. Boned Colera, Ana, "Creativas en el exilio mexicano. Apuntes biográficos y artísticos de Elvira Gascón, Remedios Varo y Manuela Ballester”, en Creatividad y sociedad, 15 (2010), p. 6. «https://docplayer.es/14558514Creativas-en-el-exilio-mexicano.html»».
} 
Además de cofundar la Unión de Escritores y Artistas Proletarios, en los años 30 la artista colaboraría con numerosas revistas de contenido cultural y político. Ejemplo de ello son la revista anarquista Estudios. Revista ecléctica o la revista antifascista Nueva Cultura. En esta última, Ballester escribiría un interesante texto denominado "Mujeres intelectuales" en el que critica la ausencia de compromiso político en las obras de mujeres artistas del momento como Ángeles Santos o Norah Borges. Afirma que han perdido su "espíritu de mujer" y se dedican exclusivamente a pintar géneros tradicionalmente considerados femeninos como bodegones florales o retratos ${ }^{19}$.

A nivel artístico, sus obras, además de mostrarse muy comprometidas socialmente, mostrarán los amplios conocimientos de Ballester del arte internacional de aquel momento. En la revista Orto publicó, por ejemplo, un fotomontaje (el primero de su carrera) llamado Las instituciones armadas cuidan de que no sea perturbada la tranquilidad de las "gentes del orden" (fig. 1) ${ }^{20}$. En este la artista toma y combina de forma magistral elementos relacionados con el fotomontaje dadaísta y las teorías del montaje de la cinematografía soviética ${ }^{21}$. Los recursos que aquí emplea Ballester tienen que ver por ejemplo con el montaje por contraste, en el que se presentan dos planos que funcionan como una comparación. En este caso, aparecen por un lado unos manifestantes de clase obrera pidiendo justicia social. Estos son detenidos por las "instituciones armadas" para que la burguesía pueda continuar sin interrupciones con su relajada y ociosa vida, en la parte superior. La artista toma sagazmente aquellos aspectos cinematográficos que más le interesan y que se adecúan a sus ideales de izquierdas para crear un lenguaje que transmita correctamente estos valores.

\footnotetext{
${ }^{19}$ Cf. Martínez Sancho, Cristina, "Compromiso político y social de Manuela Ballester", en Arte y sociedad: revista de investigación, 10 (2016), pp. 11-15. «http://asri.eumed.net/10/manuela-ballester.html».

${ }^{20}$ Muchas de las imágenes reproducidas en este artículo se encuentran en blanco y negro puesto que fueron tomadas hace tiempo por las personas que aparecen mencionadas en las fuentes. A la dificultad generalizada de encontrar fotografías de calidad de obras de artistas mujeres poco difundidas, se le suma el hecho de que algunas de las obras tratadas incluso se han perdido a día de hoy.

${ }^{21}$ Cf. Ibidem, p. 13.
} 
Figura 1. Las instituciones armadas cuidan de que no sea perturbada la tranquilidad de las "gentes del orden" (1933), Manuela Ballester.

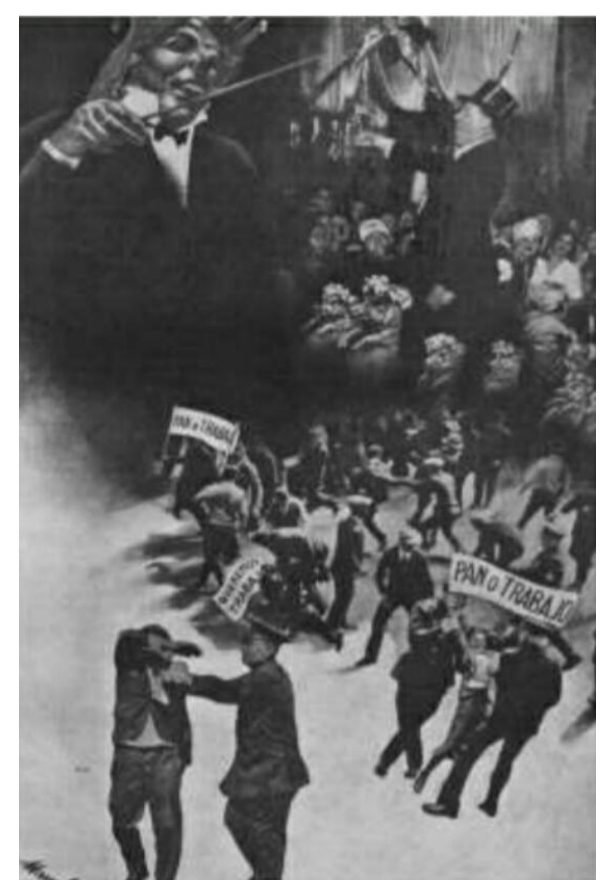

Fuente: Cristina Martínez Sancho.

Cuando encontremos a Manuela Ballester en el exilio, pese a que sí realice algunas obras murales (arte comprometido por excelencia en el México de aquel momento, como ya se ha mencionado), estas no tendrán nada que ver con el espíritu político que debía tener el muralismo ${ }^{22}$. Una de las obras más destacables, por ser los únicos murales que la artista pintó en solitario, serán los realizados para el Hotel Mocambo en Veracruz.

Para la decoración de este edificio parece que la artista realizó directamente sobre el muro distintas composiciones entre las que se encontraba una escena de sirenas. Estas obras sin embargo apenas se conocen a día de hoy, puesto que desaparecieron poco después. Es por ello que Ballester se propuso volver a decorar las paredes del hotel, pero esta segunda vez, a mediados de 1945, mediante paneles decorados, móviles. El conjunto constaba de varias composiciones que contenían, entre otros motivos, una escena de bailes autóctonos (fig. 2) o un paisaje de una playa rocosa (fig. 3$)^{23}$.

\footnotetext{
${ }^{22}$ Cf. Gaitán Salinas, Carmen, Las artistas del exilio... op. cit., pp. 149-150.

${ }^{23}$ Cf. Ibidem, pp. 151-153.
} 
Figuras 2 y 3. Sin título [Bailes] (1945), Manuela Ballester, y Sin título [Playa rocosa] (1945), Manuela Ballester.
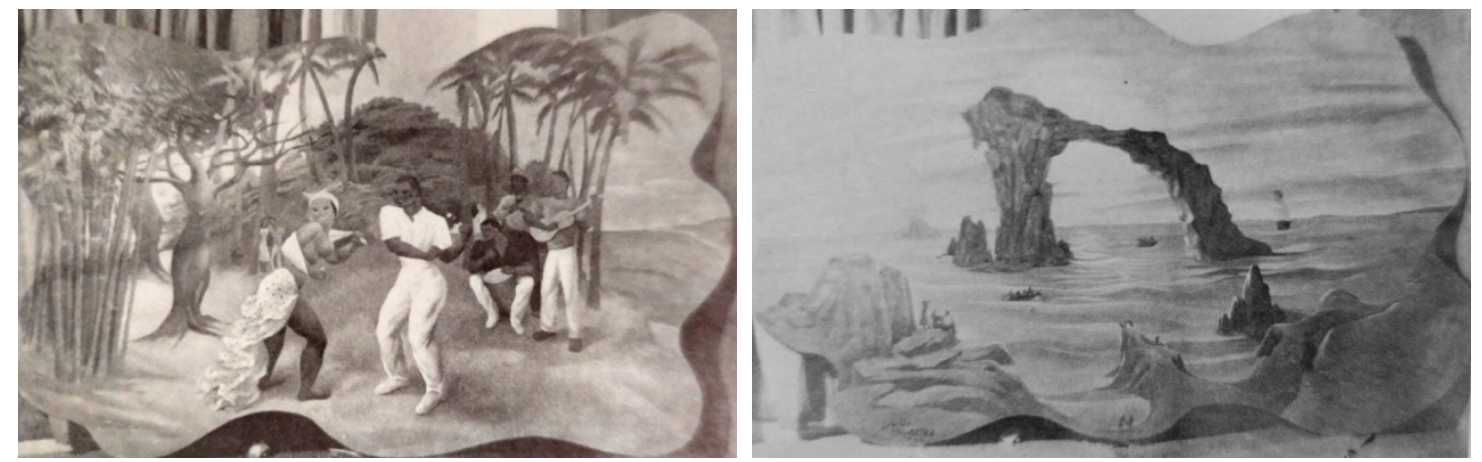

Fuente: Carmen Gaitán Salinas

Como señala Carmen Gaitán Salinas:

En los murales que participó la pintora valenciana raramente se localizan los motivos iconográficos que alentaban al muralismo mexicano. La crítica a la historia y la política de México, así como la lucha de clases, quedan por lo general al margen en estos murales que, en el caso del Hotel Mocambo, llegaban a ser únicamente decorativos, aunque algunos paneles estuvieran inspirados en las gentes autóctonas. ${ }^{24}$

Así pues, puede apreciarse cómo en estas obras el contenido expresamente político que solía tener el arte realizado por Ballester antes del exilio se ha perdido por completo. Nada tiene que ver esta obra que, como menciona Gaitán Salinas, es de contenido esencialmente decorativo, con las obras que la artista hubiera podido realizar en España, particularmente para las organizaciones políticas en las que militó. En el caso que estamos analizando, el exilio conllevó una clara despolitización artística. Una vez en el país de llegada, a Manuela Ballester la veremos pintando murales en lugares privados, cuando su vocación hasta el momento había sido el arte con proyección pública. Ella misma había criticado a Ángeles Santos o Norah Borges por realizar voluntariamente pintura decorativa ${ }^{25}$, la que ahora ella se veía obligada a realizar debido al fuerte impacto que el exilio tuvo en su trabajo. En un momento donde la necesidad generalizada de dinero para subsistir actuaba como telón de fondo, los encargos recibidos determinarían en gran medida aquello que estas artistas podían pintar, y en este caso nos alejan claramente de ese compromiso ideológico. De hecho, los murales del Hotel Mocambo, de revisarse en términos políticos, podrían vincularse a regímenes de representación que obedecen a parámetros coloniales y exotizantes. Su representación estereotipada de la población local y los escenarios artificialmente paradisíacos parecen corresponder a la visión que desde Europa se ha venido creando sobre estos lugares con fines turísticos.

\footnotetext{
${ }^{24}$ Ibidem, p. 159.

${ }^{25}$ Ver cita 19.
} 
Dentro de esta misma línea podemos acercarnos también a algunas obras de la artista Elvira Gascón. Esta se exilia en México en 1939, junto con su marido y sus hijas. Su carrera despegaría en el país de llegada en 1955 mediante una exposición individual, tras una década sin oportunidades en la que se dedicó a ilustrar para editoriales con el fin de subsistir, como le ocurrió a la mayoría de españolas ${ }^{26}$. En su obra también encontraremos un arte explícitamente político en ocasiones en las que se podía expresar libremente. Pero, además de esto, sus creaciones nos permitirán acercarnos a una noción más amplia de lo político desde un análisis metodológico feminista.

En primer lugar, y como sucedía con Manuela Ballester, hemos de tener en cuenta la clara filiación política de Gascón. Esta pintora, aunque sin un activismo político directo, se reconoce y autodenomina como republicana ${ }^{27}$. En diversos testimonios, explica que su ayuda a la República fue de carácter intelectual, a través por ejemplo de la donación de sus obras, de su trabajo ${ }^{28}$. Asimismo, denuncia la situación de España sumida en una suerte de adormecimiento, reclamando la necesidad de que despierte y se actualice. A estos efectos, señala que la República ha sido un germen importante; pese a haber fracasado, la concibe como un origen, un positivo principio para el cambio ${ }^{29}$.

Teniendo esto en cuenta, exploraremos ahora cómo la noción de lo político se manifiesta o no, y mediante qué mecanismos lo hace, en la obra de Gascón. En primer lugar, es necesario hablar, como ocurría con las obras de Ballester, de la cuestión contractual. Comenzaremos analizando por ello los murales que se le encargarán. Adelantamos ya que tampoco se le pedirán murales de contenido político, de manera que desde este plano sus posibilidades también quedarán cercenadas.

La artista no había pintado murales en España, aunque sí había estudiado el muralismo a nivel teórico, en asignaturas de Historia del $\mathrm{Arte}^{30}$. Su experimentación con obras murales, así, se desarrollará ya en el exilio. Pero Elvira Gascón no solo aprendería y adoptaría procesos del arte de México, sino que también aportaría sus propias contribuciones al mismo: emplearía la técnica del concreto teñido, inventada por ella misma. Esta consistía en la aplicación de una capa de 1,5 cm de confitillo y cemento, encima, otra de arena y cemento, y finalmente una tercera de mármol molido, sobre la que se trazaban las figuras con una punta metálica y, posteriormente, se pintaban ${ }^{31}$.

Orlando S. Suárez recoge en su Inventario del muralismo mexicano varios murales hechos por Elvira Gascón entre 1956 y 1968: la Epifanía en la Iglesia de la Medalla Milagrosa, temas

\footnotetext{
${ }^{26}$ Cf. Gaitán Salinas, Carmen, Las artistas del exilio republicano español: el refugio latinoamericano, Madrid, Cátedra, 2019, p. 240.

${ }^{27} \mathrm{Cf}$. Hernández de León-Portilla, Ascención, España desde México: vida y testimonio de transterrados, Madrid, Algaba, 2004, p. 198.

${ }^{28}$ Cf. Ibidem.

${ }^{29}$ Cf. Ibidem, p. 199.

${ }^{30}$ Cf. Ramírez Sánchez, Mauricio César, “Elvira Gascón: las líneas trasladadas a los muros”, en Crónicas, 13 (2008), p. 58. «http://www.revistas.unam.mx/index.php/cronicas/issue/view/1394/showToc».

${ }^{31}$ Cf. Ibidem, p. 59.
} 
relacionados con San Antonio en la Iglesia de San Antonio de las Huertas, San José y la Virgen para el convento de los padres Josefinos y otras dos obras murales para el Instituto de Seguridad y Servicios Sociales de los Trabajadores del Estado: una Estampida de caballos y una Guarida de tigres $^{32}$.

Figura 4. Boceto para el mural Epifanía (1956), Elvira Gascón.

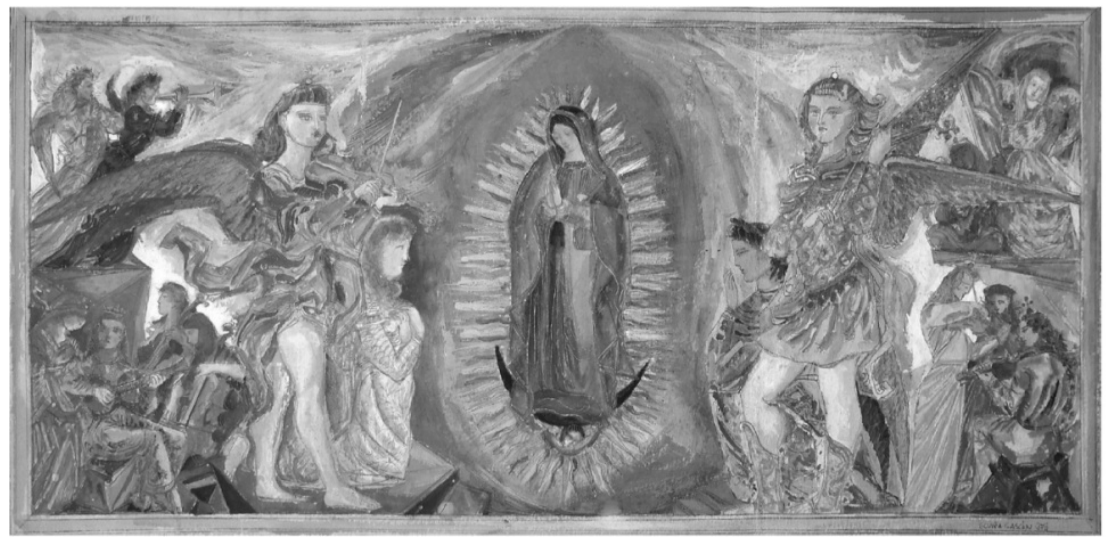

Fuente: Mauricio César Ramírez Sánchez.

La Epifanía es la adoración de los Reyes Magos a Jesús Niño. El mural que representaba este tema desapareció porque a los ángeles que rodeaban a la Virgen de Guadalupe se les veían mucho las piernas, por lo que el sacerdote decidió que se destruyeran. ${ }^{33}$ No obstante, se conserva un boceto de esta composición (fig. 4).

Figura 5. Murales de la Iglesia de San Antonio de las Huertas (1964), Elvira Gascón.

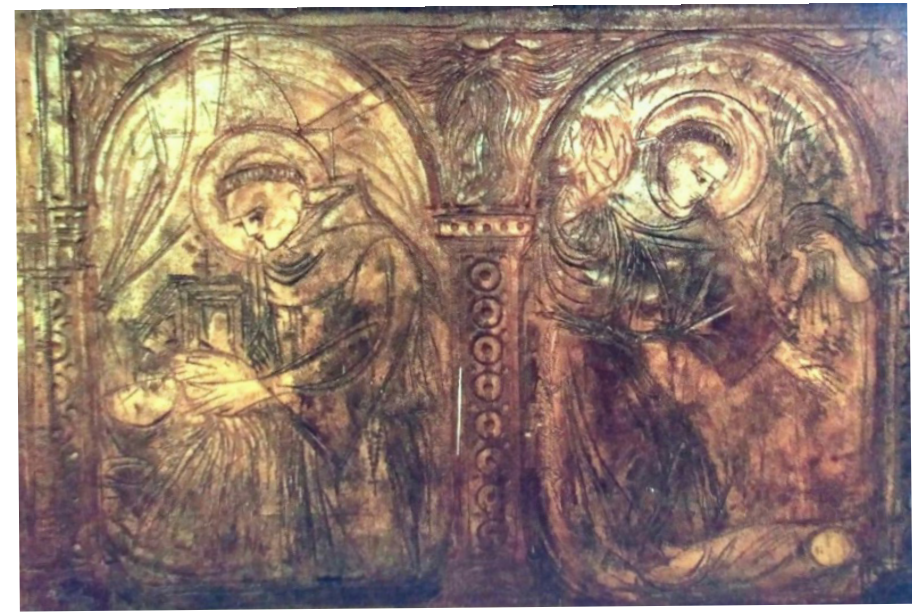

Fuente: Carmen Gaitán Salinas

\footnotetext{
${ }^{32}$ Cf. Ibidem, p. 58.

${ }^{33}$ Cf. Ibidem, p. 61.
} 
Para San Antonio de Huertas, Elvira Gascón realizaría unas escenas que en ocasiones llegaban a los seis metros de extensión, y que tenían por objetivo representar pasajes de la vida de san Antonio (fig. 5). La técnica empleada, por supuesto, sería el concreto teñido ${ }^{34}$.

Estamos, así pues, ante una artista cuyos principales encargos de obras murales tendrían que ver con edificios religiosos. Los dos únicos encargos propiamente públicos que recibió fueron los del Instituto de Seguridad y Servicios Sociales de los Trabajadores del Estado, y ni siquiera tendría ahí oportunidad para realizar temas que tuvieran alguna implicación manifiestamente política. Estas dificultades de las mujeres para acceder a obras del mismo tipo y calibre que las que se estaban encargando a los artistas varones será algo incluso sobre lo que reflexione la propia Elvira Gascón:

\begin{abstract}
Ahora estamos dormiditas. Pero deja, deja que la mujer se despierte y quiera la presidencia de la república, quiera direcciones de fábricas, exactamente igual que ellos... A ver, los lobos, a ver... Los señores se ponen ardidos cuando ven que se les iguala. Cuando son cosas pequeñas, un dibujo, un cuadro, bueno. Pero cuando he pintado murales inmensos, he notado en mis compañeros pintores unas sonrisitas pero de lo más amagas... Sí... Se fastidian. ¿Cómo es posible que una mujer se trepe a los andamios, a los tendidos?... ¿Y por qué no...? ? 35
\end{abstract}

No obstante, como se afirmaba en un principio, esta falta de implicación social en su pintura mural viene determinada por el tipo de encargos que recibía (eclesiásticos o puramente decorativos), pero si se analizan otras obras que la artista hacía de forma más libre, la situación cambia en cierta medida. Entendemos por una producción más libre aquella situación donde Gascón realizaba obras no mediadas por un contrato, y donde podía dejar espacio para plasmar tres de los principales temas que le fascinaría representar a lo largo de su carrera: la mitología clásica, la maternidad y el mundo indígena. Y es que, en 1961, Gascón realizaría una exposición en el Instituto Francés de América Latina (IFAL), llamada 15 nuevos frescos sobre paneles de Elvira Gascón. En ella, la artista presentó obras realizadas con técnicas de pintura mural pero instaladas sobre paneles, es decir, transportables ${ }^{36}$. Interesa analizar particularmente, para el tema que nos ocupa, la obra Alfabetización (fig. 6). Esta presenta un tema relacionado con las clases populares. Se vincula claramente a los valores de la izquierda que predominaban en el México de aquel momento, y especialmente en el muralismo ${ }^{37}$, como la educación universal y la alfabetización de los más humildes. Pero no solo muestra esta similitud en el tema, sino también en preceptos estéticos: las figuras rotundas, geométricas, que dan la sensación de estar inspiradas por las férreas formas del arte prehispánico, así parecen evidenciarlo.

\footnotetext{
${ }^{34}$ Cf. Ibidem, p. 59.

${ }^{35}$ Ibidem, p. 67.

${ }^{36}$ Cf. Gaitán Salinas, Carmen, Las artistas del exilio... op. cit., p. 163.

${ }^{37}$ A esta relación de Alfabetización con el muralismo ya apuntaba Carmen Gaitán Salinas. Cf. Ibidem, pp. 63-64.
} 
Figura 6. Alfabetización (1961), Elvira Gascón.

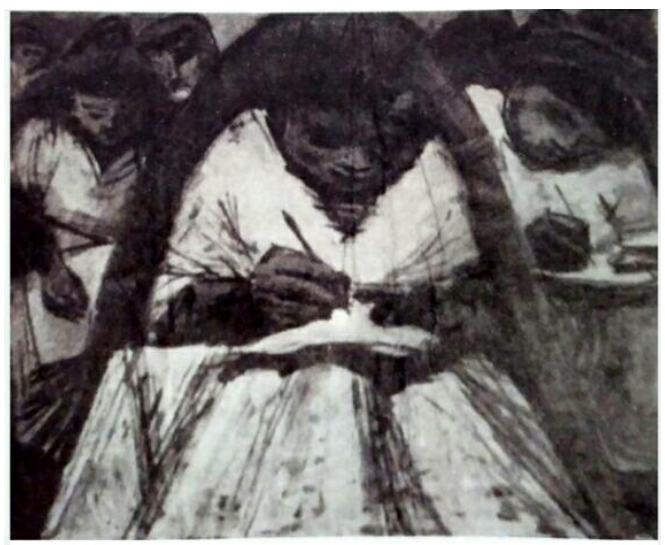

Fuente: Carmen Gaitán Salinas.

Estas nociones son las que podemos analizar por lo que respecta a un estudio en el sentido estricto y tradicional de las iconografías entendidas como políticas. No obstante, de acuerdo con las perspectivas metodológicas de la historia del arte feminista a la que nos adherimos, el análisis de las obras no debe quedar aquí. La noción de lo político, desde el punto de vista de los estudios de género, alberga un significado más amplio y complejo que hemos de abordar de cara a lograr una relectura más completa de las obras producidas por estas mujeres. La teórica feminista Kate Millett, en su paradigmática obra Política sexual, señala que, en su intento de esbozar "unos cuantos apuntes encaminados hacia una teoría del patriarcado"38, se propone demostrar "que el sexo es una categoría social impregnada de política" ${ }^{39}$. Así, de cara a considerar la relación existente entre los géneros desde un punto de vista político, la definición que ofrece Millet de la política:

no se refiere tan solo al limitado mundo de las reuniones, los presidentes y los partidos, sino, por el contrario, al conjunto de relaciones y compromisos estructurados de acuerdo con el poder, en virtud de los cuales un grupo de personas queda bajo el control de otro grupo[...]. Resulta posible utilizar la palabra 'política' al referirse a los sexos porque subraya la naturaleza de la situación recíproca que estos han ocupado en el transcurso de la historia y siguen ocupando en la actualidad. ${ }^{40}$

Así, político es también todo aquello referido a las relaciones sociales que establecen privilegios y dominancia de unos grupos sociales sobre otros, como ocurre con los hombres respecto de las mujeres en la sociedad patriarcal. Políticos son aquellos factores sociales relacionados de manera evidente con el género.

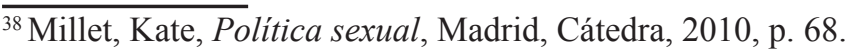

${ }^{39}$ Ibidem.

${ }^{40}$ Ibidem.
} 
Dentro de este sentido político tangencial al género, el arte evidentemente cuenta con un papel fundamental. Ahondando en esta cuestión ya estrictamente en la disciplina historiográfica, la historiadora del arte feminista Griselda Pollock en su libro Visión y diferencia: feminismo, feminidad e historias del arte, habla sobre el sentido político del arte, explicando que "las prácticas culturales tienen una función de gran significación social en la articulación de sentidos para comprender el mundo, en la negociación de conflictos sociales, en la producción de sujetos sociales" ${ }^{41}$.

Particularmente dentro de estas nociones, lo que nos interesa es el arte como productor de sujetos sociales adscritos a los roles de género, es decir, en lo referente a la feminidad y la masculinidad tradicionales y hegemónicas. Porque, si las obras culturales y artísticas pueden utilizar esta capacidad transformadora en pro de la organización social patriarcal y tradicional, para el individuo pueden ser también un sitio de lucha. Este potencial puede ser aprovechado para modificar los parámetros tradicionales: "por eso se las puede concebir como lugares de modificación o subversión" ${ }^{\text {"2 }}$. Así, arte político (en el sentido del género) será también el que, en base a su capacidad de producción de sujetos sociales, altere la visión tradicional de la feminidad produciendo nuevos modelos de subjetividad femenina. Veamos ahora cómo algunas de las obras producidas por Elvira Gascón en el exilio se adhieren a este concepto de lo político entendido desde los estudios de género.

Como ya se ha mencionado anteriormente, uno de los temas pictóricos predilectos de esta artista serían las maternidades. Dentro de los aspectos que más destacó la crítica sobre su obra encontramos el acierto de elegir a las mujeres y los niños locales para denunciar la situación del pueblo mexicano ${ }^{43}$, algo que constituye una clara denuncia política. En su obra Maternidad de 1955 (fig. 7) Elvira Gascón utiliza la figura de la madre para ilustrar la pobreza y las duras condiciones de la vida indígena en aquel momento. Si bien los pueblos originarios se habían exaltado en las políticas nacionalistas o los programas culturales como el muralismo de Vasconcelos, la realidad es que estos sectores sociales indígenas apenas recibieron ayudas gubernamentales. Gascón retrata a esta madre como denuncia de la precariedad, para mostrar la crudeza de la vida. Lo hace mediante las corporalidades de la mexicanidad, mediante la representación de la mujer mexicana, adoptando los nuevos sujetos sociales que estaba percibiendo en su país de llegada e incorporándolos como esencia de sus pinturas. Pero no con una fetichización racista, no con la voluntad de pintar retratos amables de las gentes consideradas “exóticas" según la perspectiva eurocéntrica, sino adentrándose en la cotidianeidad de estas mexicanas que compartían con ella dos denominadores comunes: su género y el destierro político. Así pues, esta iconografía de la maternidad en Elvira Gascón no se entiende sin el exilio.

\footnotetext{
${ }^{41}$ Pollock, Griselda, Visión y diferencia: Feminismo, feminidad e historias del arte, Buenos Aires, Fiordo, 2013, p. 31 . 42 Ibidem

${ }^{43}$ Cf. Gaitán Salinas, Carmen, Las artistas del exilio... op. cit., p. 240.
} 
Figura 7. Maternidad (1955), Elvira Gascón.

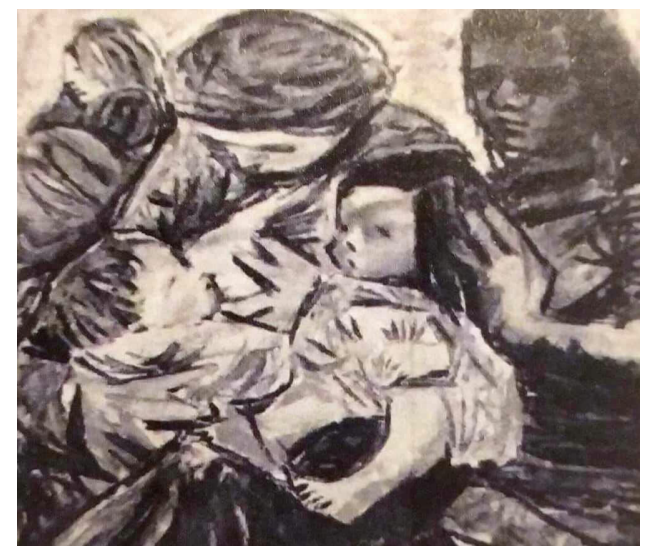

Fuente: Carmen Gaitán Salinas.

Pero ahondemos más allá: ¿en qué medida esta iconografía de Gascón está transformando la representación de la feminidad tradicional, de manera que pueda leerse de forma política en los términos que hemos establecido?

Sin que sea el objetivo de este estudio profundizar en la historia de la iconografía de la maternidad, cabe esbozar algunas pinceladas al respecto con el fin de entender la importancia de aportaciones como la de Gascón. Si analizamos la representación de la maternidad según la concepción tradicional de la feminidad (un buen ejemplo es el cuadro de Renoir, fig. 8), cabe señalar que en ellas opera una iconografía de la mujer feliz, retratada con su hijo en brazos, venerando ese deseo maternal idílico de protección y cuidado. Dichas visiones presentan a la madre dando el pecho, con un gesto dulce y cariñoso, vinculado al tópico del escenario natural que ofrece una manida asociación entre mujer, felicidad y naturaleza, y en cuyas descripciones se suele hablar de candidez, inocencia y felicidad ${ }^{44}$. La felicidad de quien parece haber ya con su único objetivo vital como continuadora de la especie ${ }^{45}$.

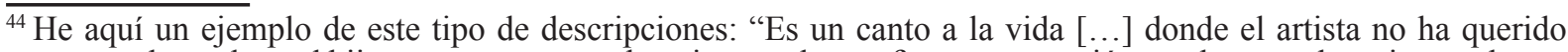
encerrar a la madre y al hijo entre cuatro paredes, sino que los prefiere en comunión con la naturaleza, insertados en ella, participando de ella no solo por su presencia sino también por el hecho mismo natural del amamantamiento. Es la entrega alegre, despreocupada y confiada a la vida, donde la mujer [...] descansa en el árbol como el niño en la mujer". [De Llano Varela, Cristina, "Maternidad en el arte o el arte de la maternidad", en Revista padres y maestros, 122 (1996), pp. 23-25].

${ }^{45}$ Sobre las representaciones tradicionales de la maternidad, ver también Hervás Hermida, Lucía, "Las imágenes de las artistas y sus maternidades", en Arteterapia, 24 (2016).
} 
Figura 8. Maternidad (1885), Pierre-Auguste Renoir.

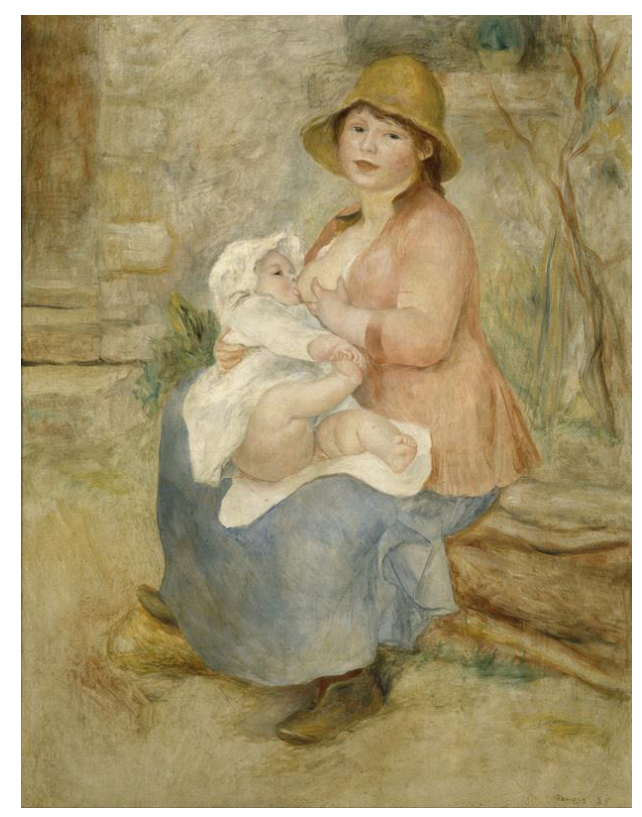

Fuente: artgeist.es.

Elvira Gascón, no obstante, está transformando de manera radical esta concepción tradicional de la madre. Utiliza su imagen para hablar de sufrimiento, de angustia. La maternidad aquí se vincula a la pesadez con la que se ha de sostener a esos rotundos niños, a la precariedad, a la crudeza de la vida ${ }^{46}$. Transforma la imagen de esta mujer, pasando del icono de perfección y dulzura que obtiene su completa felicidad exclusivamente a raíz de dar a luz para presentarnos a una mujer a la que le preocupan muchas otras cosas, a una mujer real. El espacio ya no es natural y armonioso, sino agobiante, marcado por el movimiento de sus rápidas pinceladas y la proliferación de figuras que parecen cernirse con prisa en torno a la madre, incluso empujándola para que avance. Las mujeres no aparecen ya como objetos pasivos observados por ojos masculinos, sino que introducen su propia experiencia: Gascón era bien consciente de lo que implicaba atravesar vicisitudes políticas y migratorias cargando con una familia, y el resultado es, ni más ni menos, la transformación en sus pinturas del sujeto femenino tradicional según postulaba Pollock.

Sin embargo, dentro de esta ampliación de la noción de lo político también cabría considerar otras cuestiones. ¿Acaso resulta desafiante para con los cánones impuestos, también, el hecho de que Gascón elaborase iconografías como la de los ángeles de la Iglesia de la Medalla Milagrosa, que hubieron de ser destruidos por considerarse provocadores?

\footnotetext{
${ }^{46}$ Sobre esta concepción pictórica de la maternidad vinculada a la pesadez y la precariedad (dentro de lo que se podría denominar como "iconografía de la carga"), ver Garbayo-Maetzu, Maite, "Maternidad, arte y precariedad: estrategias desde la vulnerabilidad", en Arte y politicas de identidad, 19 (2018), p. 69. https://doi.org/10.6018/ $\underline{\text { reapi. } 359781}$
} 
Por todo ello, dentro del sentido político en relación con la producción de las artistas entra toda una serie de factores adicionales que no tienen por qué estar relacionados con la representación de temas explícitamente políticos. Es un hecho que la posibilidad de realizar obras con este tipo de contenido manifiesto quedó en gran parte cercenada para estas artistas en el exilio. Pero es igualmente cierto que en el estudio de las implicaciones políticas de su obra hemos de analizar, de acuerdo con la historiografía del arte feminista, muchos otros factores como los que aquí acabamos de exponer. Estos también incluyen la producción de iconografías que, por modificar la noción patriarcal de la mujer, han de ser entendidas en el sentido político que se contempla desde los estudios de género.

\subsection{Influencias del arte mexicano en las prácticas artísticas de las españolas}

Se pretende analizar ahora el impacto que tuvo la cultura artística mexicana en la obra de dos artistas españolas. A pesar de que el tema de las prácticas artísticas podría enfocarse desde múltiples vías de análisis y englobar manifestaciones muy variadas, nos centraremos concretamente en dos tipos de prácticas: una relacionada con el modus operandi de varios artistas mexicanos a la hora de pintar su entorno, con Pilar Puig, $y$, en segundo lugar, otra práctica relacionada con la adopción de las técnicas típicamente mexicanas, de la mano de Marta Palau.

La artista Pilar Puig sería una de las pocas mujeres que conseguiría realizar exposiciones individuales durante los años 40 en México. El número de exposiciones monográficas que se les dedicaron a los artistas masculinos exiliados es mucho mayor que el que lograrían estas mujeres. Esto es algo en lo que, según Carmen Gaitán Salinas, influirían enormemente las trabas puestas por el cuidado de la familia y por la dedicación a otros trabajos que no les permitían el tiempo para dedicarse como querían a la producción artística ${ }^{47}$. En marzo de 1955, Puig realizaría una exposición individual que constaría de casi treinta dibujos del antiguo imperio maya y más de treinta y cinco pinturas (figs. 9 y 10). Esta muestra era el resultado del gran interés que la artista había experimentado, desde que empezara la década de los 50 , por las culturas americanas. Esta inclinación por el mundo prehispánico la llevaría a emprender distintos viajes por el territorio que había visto nacer a los mayas para dibujar los restos de su cultura ${ }^{48}$.

Con esta manera de proceder, la pintora parece adscribirse a una práctica habitual entre los artistas mexicanos. Desde los primeros tiempos del muralismo, allá por la época del pintor Gerardo Murillo a principios del siglo xx, puede apreciarse cómo será una tendencia habitual la de recorrer durante varias semanas el país para estudiar y dibujar los restos prehispánicos. Esta tradición será continuada por los muralistas de los años 20. Ellos también viajarán para conocer

\footnotetext{
${ }^{47}$ Cf. Gaitán Salinas, Carmen, Las artistas del exilio... op. cit., p. 232

${ }^{48}$ Cf. Ibidem, pp. 232-233.
} 
las zonas más profundas de México, con el fin de documentarse acerca de las culturas indígenas que debían plasmar en sus obras públicas.

Figuras 9 y 10. Ilustración para Los mayas en su esplendor (1955), Pilar Puig, e ilustración para Los mayas en su esplendor (1955), Pilar Puig.
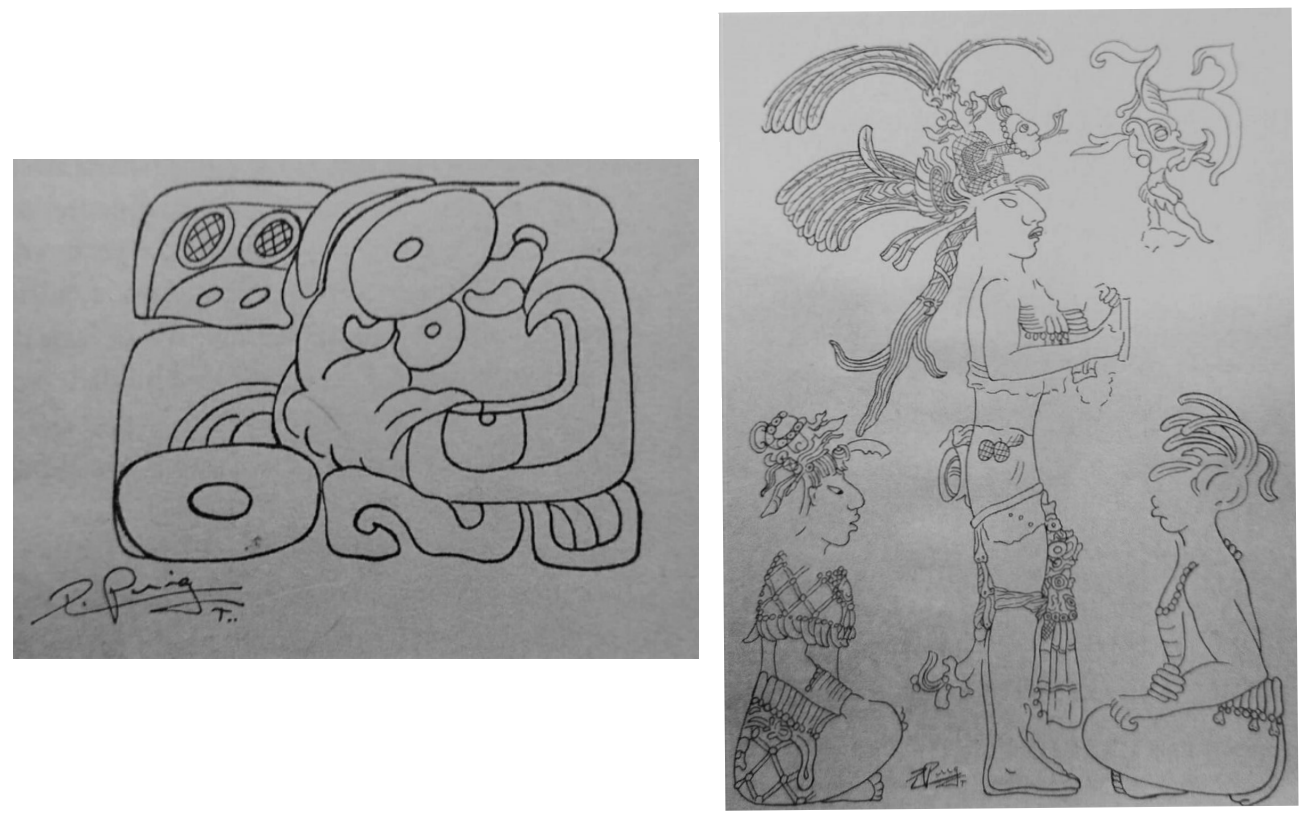

Fuente: Carmen Gaitán Salinas

Un referente en lo que a adopción de técnicas mexicanas se refiere será Marta Palau. Esta llegó a México en 1940, cuando tan solo contaba con seis años de edad, perteneciendo por tanto a la segunda generación de exiliadas. Tras experimentar con pintura y grabado, irrumpió en el panorama del textil mexicano en 1972. La técnica con la que comenzó a trabajar fue el sarape, nacida en México tras la conquista, cuando se conoció la lana y el telar híbrido (puesto que antes se tejía con fibras de algodón, de maguey y pelo de animal y plumas mediante un telar de cintura $)^{49}$. Pero además esta artista será paradigmática en lo que a síntesis cultural en el exilio se refiere, puesto que sobre esta base mexicana integrará también nociones vinculadas a la tapicería española. En ella destacaban figuras como Josep Grau Garriga, artista catalán del nuevo tapiz contemporáneo característico por su uso novedoso de materiales y formas del que Palau tomaría elementos como la mezcla entre lo delicado y lo ligado a la brutalidad ${ }^{50}$.

En la década de los 80, Marta Palau realizaría un conjunto de treinta obras textiles bajo el nombre Mis caminos son terrestres donde explora la esencia de lo mexicano: la cultura del maíz, las formas compactas del arte precolombino, el protagonismo de la luz que penetra en la

\footnotetext{
${ }^{49} \mathrm{Cf}$. Tibol, Raquel, "Los caminos de Marta Palau y del tapiz en México", en Revista de la Universidad de México, 415 (1985), pp. 26-27. «https://www.revistadelauniversidad.mx/articles/a72c21c7-f8d8-470a-bee2-1eeef025ce99/ los-caminos-de-marta-palau-y-del-tapiz-en-mexico»».

${ }^{50}$ Cf. Ibidem, p. 28.
} 
obra al igual que ocurría con la arquitectura indígena, etc. ${ }^{51}$. Algunas de las obras que permiten ir viendo su evolución son Alpha (fig. 11) o Ilerda (fig. 12).

Figura 11. Alpha (1976), Marta Palau.

Fuente: Museo Tamayo.

Figura 12. Ilerda (1973), Marta Palau.
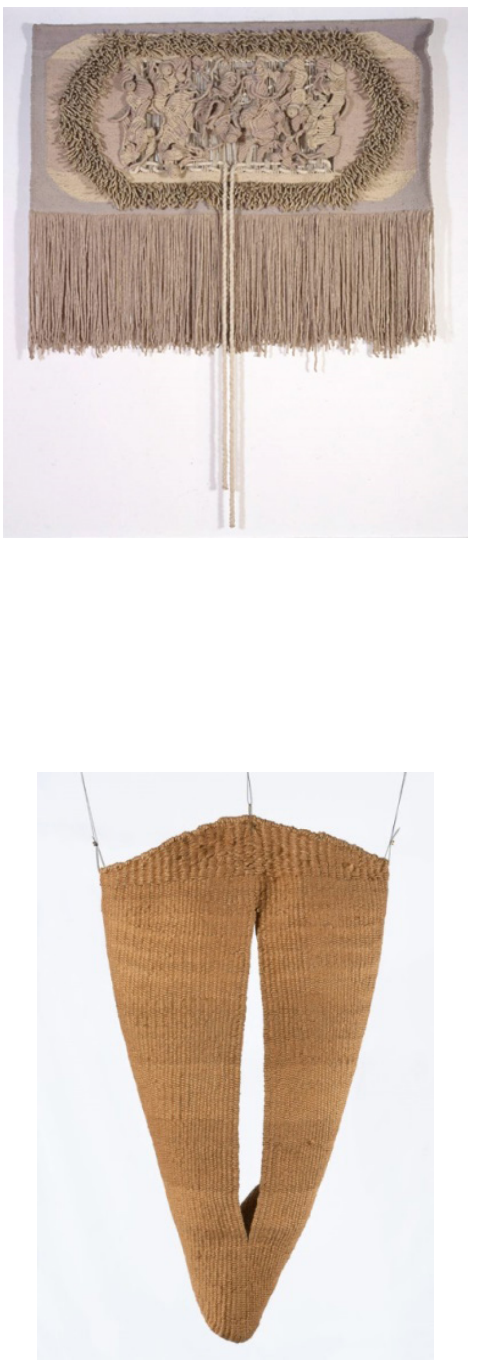

Fuente: Diari La Veu.

Mediante sus materiales, la artista remite al mundo natural y a las tradiciones de las culturas prehispánicas, adquiriendo especial importancia lo chamánico y la figura de la mujer. Rendirá tributo a la figura de la naualli, palabra que en la lengua náhuatl significa "mujer protectora", "hechicera" o "mujer de poder" 52 . Se trata del arquetipo femenino de la cultura chamánica, asimilada con el origen de toda vida ${ }^{53}$. Así, en obras como Naualli guerrera (fig. 13) reivindicará, además del arte popular, el papel de la mujer en las culturas prehispánicas. Existe, en este sentido, un aspecto vinculado a la obra de Marta Palau al que se ha atendido

\footnotetext{
${ }^{51}$ Cf. Ibidem.

${ }^{52}$ Arteinformado, "Marta Palau: tránsitos de naualli". «https:/www.arteinformado.com/agenda/f/marta-palautransitos-de-naualli-92509»».

${ }^{53}$ Cf. Navarrete, Sylvia, "Helen Escobedo y Marta Palau: suman años y arte", Reforma, 6 (2005), p. 2. «https:// search-proquest-com.bucm.idm.oclc.org/docview/307559463»".
} 
ampliamente desde los estudios de género: el concepto de la genealogía femenina. Esta idea, a la que se aproximan desde la Historia del Arte figuras como Patricia Mayayo ${ }^{54}$, fue reivindicada ya en 1929 por Virginia Woolf. En Una habitación propia, esta autora apela a la necesidad de crear una tradición de referentes femeninos invisibilizados a lo largo de la historia.

\begin{abstract}
Porque, si somos mujeres, nuestro contacto con el pasado se hace a través de nuestras madres. Es inútil que acudamos a los grandes escritores varones en busca de ayuda, por más que acudamos a ellos en busca de deleite. Lamb, Browne, Thackeray, Newman, Sterne, Dickens, De Quincey — cualquieranunca han ayudado hasta ahora a una mujer, aunque es posible que le hayan enseñado algunos trucos que ella ha adoptado para su uso. El peso, el paso, la zancada de la mente masculina son demasiado distintos de los de la suya para que pueda recoger nada sólido de sus enseñanzas. [...] Quizá lo primero que descubrió la mujer al coger la pluma es que no existía ninguna frase común lista para su uso..$^{55}$
\end{abstract}

Rindiendo homenaje a una figura como la naualli en su obra, Marta Palau se adscribe a una tradición femenina. Concretamente, a la tradición cultural de las mujeres mexicanas, creando su genealogía propia a partir de la herencia de su país de llegada. Dentro de los significados que acompañan a la figura de la chamana, hay que recordar que en las culturas prehispánicas las mujeres mayores eran consideradas como sabias y curanderas. Pero, con el paso del tiempo, sus atributos fueron desplazados por la violencia patriarcal de los sacerdotes y médicos, existiendo una tendencia por los varones de adquirir las actividades desarrolladas desde tiempo atrás por las mujeres ${ }^{56}$.

Figura 13. Naualli guerrera (2009), Marta Palau.

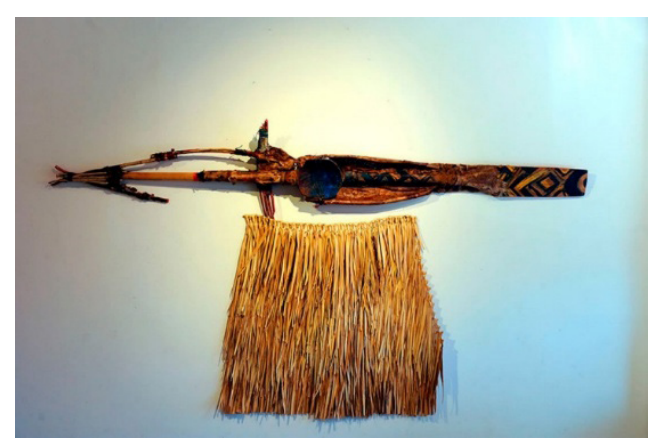

Fuente: Museo de Mujeres Artistas Mexicanas.

En esta línea, cabe señalar otro aspecto clave como son las implicaciones que tiene el arte textil particularmente desde la perspectiva de género. Son muchas las historiadoras del arte que han abordado esta temática. Griselda Pollock explica que las formas de creación tradicionalmente

\footnotetext{
${ }^{54}$ Cf. Mayayo, Patricia, Historias de mujeres, historias del arte, Madrid, Cátedra, 2017, pp. 72-87.

${ }^{55}$ Woolf, Virginia. Una habitación propia, Seix Barral, Barcelona, 2008, p. 55.

${ }^{56}$ Cf. Graciela Hierro et al., "Mujer y madurez: un futuro de esperanza", en Blanco Figueroa, Francisco (dir.), Mujeres mexicanas del siglo XX: la otra revolución, t. 1, México, Edicol, 2001, pp. 63-89.
} 
ligadas a las mujeres se han venido considerando "artes populares" o "artesanías", y que la división entre Bellas Artes y arte popular se encuentra afectada por el género, puesto que las obras producidas por la creatividad masculina occidental son las únicas que se presentan como sinónimo de arte. Esto "marca una exclusión y devaluación que hace que se desprecie o ignore la actividad cultural y creativa producida por mujeres" 57 .

Eli Bartra, historiadora del arte especializada en perspectiva de género y decolonial, pone énfasis en el hecho de que el arte popular producido por hombres no se devaluará en la misma medida, de forma que, aunque se haga referencia a pueblos enteros de alfareras como Ocumicho en Michoacán, se habla de "los alfareros", pensándose que se les hace un favor a las mujeres por ligarlas con la idea del genio productor masculino ${ }^{58}$. Igualmente, esta autora alude a la relevancia y necesidad de recoger las experiencias de las mujeres creadoras de arte popular puesto que estas han pasado a la historia como sujetos anónimos y sin reconocimiento público ${ }^{59}$. Palau retoma en su obra el legado de mujeres transmisoras de la cosmovisión milenaria de sus pueblos, contribuyendo, según los parámetros que enunciaba Bartra, a la revalorización del arte popular y la mujer como creadora bajo parámetros no occidentales.

\subsection{Las iconografías de las artistas y el impacto del exilio}

En relación con este último apartado, hemos de mencionar que evidentemente se podrían analizar muchos tipos de iconografías, incluso las de obras a las que ya nos hemos aproximado en este estudio, lo cual es una prueba más de que estas producciones pueden y deben ser abordadas desde múltiples perspectivas que intersecan entre ellas. Las representaciones de Elvira Gascón en las que se introduce la noción de la mexicanidad, por ejemplo, no dejan de ser iconografías que muestran el impacto que el exilio tuvo sobre el repertorio cultural y visual de esta artista.

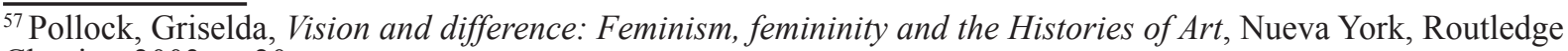
Classics, 2003, p. 20.

${ }^{58}$ Cf. Bartra, Eli, “Apuntes sobre feminismo y arte popular”, en Bartra, Eli y María Guadalupe Huacuz Elías (coords.), Mujeres, feminismo y arte popular, México, Obra Abierta, 2014, p. 29.

${ }^{59}$ Ibidem, p. 12.
} 
Figura 14: Mujer con niño (1976), Mary Martín.

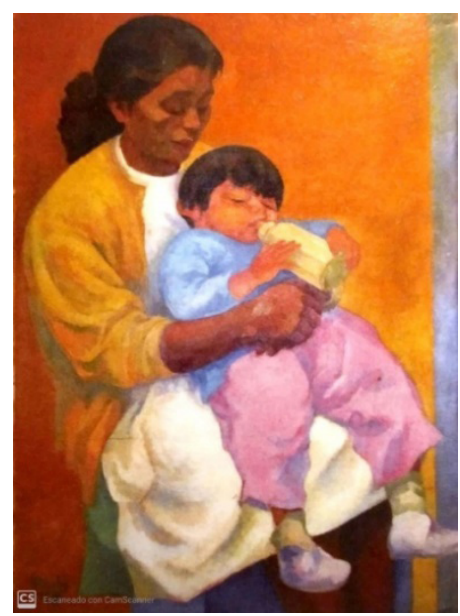

Fuente: Carmen Gaitán Salinas.

Continuando con esta idea de las representaciones que ahondan en la cotidianeidad mexicana, conviene analizar la obra de Mary Martín. Nacida en Salamanca en 1927, pertenece, como Palau, a la segunda generación de exiliadas. En esta artista será fundamental la representación de la mujer mexicana como protagonista de sus obras. Retrata también, como Gascón, a madres mexicanas en escenas relacionadas con su vida diaria, y sin una visión idealizada. Esto es lo que encontramos en Mujer con niño (fig. 14), donde rostro de cansancio de la mujer, con esos marcados pómulos, resulta muy revelador.

Pero su representación de la mexicanidad también se adentrará en un terreno mucho más íntimo, a través de la plasmación de cuerpos desnudos. Así describía ella sus desnudos femeninos (figs. 15 y 16):

Me gusta pintar a la mujer, pintarme a mí misma[...]. No me interesa tanto mostrar una figura bonita[...]. Me interesa mostrar a la mujer plena, registrar las formas, las expresiones, los ángulos, las carnes, la violencia de los colores[...]. Cuando la mujer pinta a la mujer la pinta en un ámbito diferente, más íntimo, más doméstico. Porque la mujer siente la necesidad de reflejarse tal y como es, y el hombre nos refleja tal y como cree que somos o como quisiera que fuéramos. $\mathrm{O}$ nos idealiza o nos convierte en objetos de placer. ${ }^{60}$

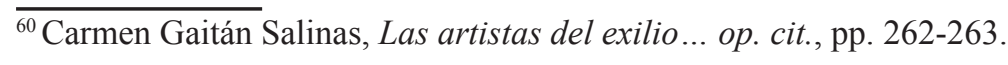


Figuras 15 y 16: Desnudo (sa) y Sin título (1977), Mary Martín.

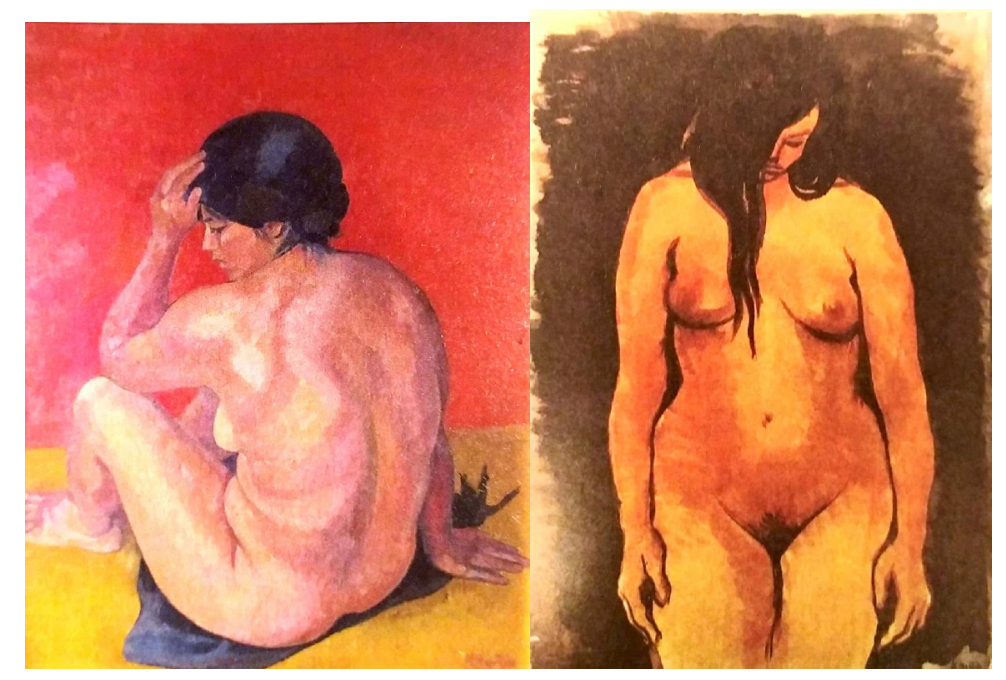

Fuente: Carmen Gaitán Salinas

No encontramos una representación selectiva o idealizada del cuerpo de la mujer, no se fija la atención solo en aquellas zonas sexualizadas. Ahora se representa toda la mujer, toda su fisicidad, también aquella que "no agrada" según los cánones tradicionales. También las carnes menos tersas, los pechos más caídos o más pequeños. En esta voluntad por representar fielmente la realidad de las mujeres, Mary Martín atenderá igualmente a su diversidad. Es por ello que introduce en sus cuadros los cuerpos de las mujeres mexicanas, alejadas del estereotipo blanco, caucásico. La introducción de las mujeres de rasgos marcadamente indígenas y las iconografías que le proporciona el exilio, en este caso funcionan como un vector más de los que la artista escoge para representar la realidad y pluralidad del género femenino.

Muy interesantes son a nivel iconográfico también las obras de Remedios Varo. Esta artista muestra otro tipo de manifestación del exilio en sus iconografías, que tiene que ver particularmente con el proceso migratorio en sí. En su obra el exilio se representará a partir de personajes que van con su casa a cuestas, que se desplazan constantemente. Dichas figuras aparecen acompañadas por elementos como ruedas, que aluden a ese movimiento, y distintos elementos mecánicos que son la extensión de sus extremidades (fig. 17). De hecho, este tema será el que se manifieste en la única escultura realizada por la artista, Homo rodans ${ }^{61}$ (fig. 18).

\footnotetext{
${ }^{61}$ Cf. Valcárcel, Carmen, "Remedios Varo: espacios de la creación", en Millares, Selena (ed.), Diálogo de las artes... op. cit., pp. 415-418.
} 
Figuras 17 y 18: Emigrantes (1962) y Homo rodans (1959), Remedios Varo.
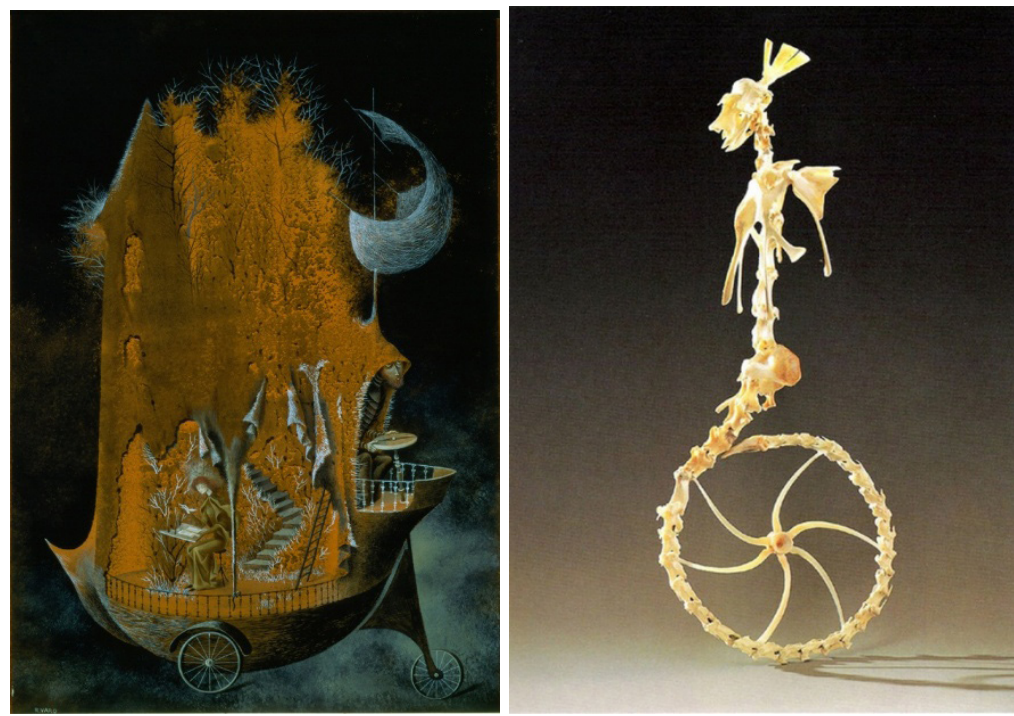

Fuente: remedios-varo.com

Con Varo puede verse por tanto otro tipo de iconografía: ya no se implementan en las obras de arte los nuevos personajes que la artista estaba percibiendo en el entorno mexicano. Lo que se revaloriza y plasma ahora es la propia experiencia del exilio, del movimiento entre dos lugares. Hemos de recordar, a estos efectos, que Remedios Varo perteneció a la primera generación de artistas, aquellas que emigraron ya adultas y con una vida previamente establecida en España. Mediante estas obras manifiesta la sensación constante entre las exiliadas de identidad inestable, de quien vaga de un sitio a otro sin llevar apenas pertenencias con él. También la concepción de hogar itinerante, de una casa que, a pesar de estar bien asentada anteriormente, en aquel momento se había visto obligada a vagar en busca de una nueva ubicación a salvo.

\section{Conclusiones}

Las repercusiones que tuvo el exilio en la vida y obra de las artistas que se vieron forzadas a emigrar a México es una cuestión que ha de comenzarse a abordar en mayor medida desde la historiografía artística. Como se observa a partir de los ejemplos analizados, la impronta del exilio en las obras producidas por las españolas tiene multitud de manifestaciones. Se ha podido comprobar claramente cómo el país americano les abrió la puerta a muy variadas realidades desconocidas hasta el momento: nuevas tradiciones, nuevos personajes que incorporar a sus obras, renovados conocimientos sobre técnicas artísticas, concepciones de un arte público 
en originales formatos y un pasado y una cultura que disentían mucho de la de su país de procedencia. Si efectivamente existe una historia diferente por cada exiliada, el campo de estudio que tiene por delante la Historia del Arte es vasto; no obstante, habremos de armarnos de valor para explorarlo, pues, como afirma Concha Pando Navarro:

Plantear el estudio de colectivos como el de las mujeres representa una dificultad añadida a la de cualquier otro trabajo. En primer lugar, resulta difícil delimitar un grupo en función de su género, grupo no siempre homogéneo y no aislado del resto de la sociedad, $y$, en segundo lugar, porque supone un acercamiento a un sector olvidado en casi todas las historias oficiales de nuestro pasado y, por supuesto, de nuestro presente. ${ }^{62}$

\footnotetext{
${ }^{62}$ Pando Navarro, Concha, "Las mujeres españolas en México: emigración y exilio", en Andreo García, Juan et al. (eds.), Familia, tradición y grupos sociales en América Latina, Murcia, Universidad de Murcia, 1994, p. 131.
} 